\title{
Regulation, Supervision and Social and Financial Efficiency of Microfinance Institutions in ASEAN-5 Countries
}

\author{
Nurazilah Zainal ${ }^{\mathrm{a}}$ \\ Universiti Teknologi MARA \\ Fakarudin Kamarudin ${ }^{b}$ \\ Universiti Putra Malaysia \\ Law Siong Hook ${ }^{\mathrm{c}}$ \\ Universiti Putra Malaysia \\ Mohammed Hariri Bakrid \\ Universiti Teknikal Malaysia \\ Fadzlan Sufian ${ }^{\mathrm{e}}$ \\ Universiti Teknologi MARA \\ Annuar Md Nassir ${ }^{\mathrm{f}}$ \\ Xiamen University Malaysia
}

\begin{abstract}
This study delivers new empirical evidence on the impact of banking regulations on the levels of social and financial efficiency of microfinance institutions (MFIs) between the years 2012 to 2018. The sample consisted of data from $172 \mathrm{MFIs}$ from ASEAN-5 countries. As the first stage of the analysis, data envelopment analysis (DEA) was employed to determine a score of the level of social and financial efficiency for the sampled MFIs. Meanwhile, panel regression analysis and the Generalized
\end{abstract}

a Faculty of Business and Management, Universiti Teknologi MARA Campus Seremban 3, 70300 Seremban, Negeri Sembilan. Email: nuraz3169@uitm.edu.my (Corresponding author)

b School of Business and Economics, Universiti Putra Malaysia, 43400 Serdang, Selangor, Malaysia. Email: fakarudin@upm.edu.my

c School of Business and Economics, Universiti Putra Malaysia, 43400 Serdang, Selangor, Malaysia. Email: lawsh@upm.edu.my

d Faculty of Technology Management and Technopreneur, Universiti Teknikal Malaysia, Jalan Hang Tuah Jaya, 76100 Durian Tunggal, Melaka. Email: hariri@utem.edu.my

e Faculty of Business and Management, Universiti Teknologi MARA Campus Puncak Alam, 42300 Kuala Selangor, Selangor. Email: fadzlansufian@uitm.edu.my

f School of Economics and Management, Xiamen University Malaysia Jalan Sunsuria, Bandar Sunsuria, 43900 Sepang, Selangor. Email: annuar.nassir@xmu.edu.my

* The authors would like to thank the editors and the anonymous referees of the journal for their constructive comments and suggestions, which have significantly helped to improve the paper. Furthermore, special thanks to: 1) Fundamental Research Grant Scheme (FRGS) Project Code: 600- IRMI/FRGS 5/3 (141/2019) sponsored by Malaysian Ministry of Higher Education; 2) Universiti Teknologi MARA, Malaysia; and 3) Universiti Putra Malaysia Grant IPS Vot No. 9651500 sponsored by Universiti Putra Malaysia as organisations that funded our research. The usual caveats apply.

Article Info: Received 26 July 2019; Revised 31 May 2020; Accepted 29 September 2020

https://doi.org/10.22452/MJES.vol57no2.5 
Method of Moments (GMM) estimator were used to examine the impact of banking regulations on the level of social and financial efficiency of the sampled MFIs. The findings showed that the sampled MFIs achieved a lower level of social efficiency while attaining a higher level of financial efficiency. The lower level of social efficiency indicated that the sampled MFIs had lost their focus on poverty reduction, while at the same time, switching their focus toward financial sustainability. The empirical findings also showed a significant impact of bank regulation and bank supervision on the levels of social and financial efficiency. Overall, bank regulation negatively influenced the level of social efficiency and bank supervision impacted the level of financial efficiency of the sampled MFIs positively. The findings from this study provide new insights for bank regulators and policymakers to construct regulatory frameworks that are relevant to the operation of MFIs.

Keywords: Financial efficiency, microfinance institutions, regulation, social efficiency, supervision

JEL classification: G01, G21, G28

\section{Introduction}

Choosing the correct perspective on the issue of poverty in the current era is a significant question for the global community. The establishment of microfinance institutions (MFIs) has addressed the failure of commercial banks to offer financial services to poorer people. Since the early 1970s, the work undertaken by the Bangladeshi professor of economics, Muhammed Yunus (who has been awarded the Nobel Peace Prize), introduced MFIs as providers of financial services mainly to poorer households, especially in the rural areas of Bangladesh. Over the years, the scope of MFIs has evolved and expanded from its initial relatively narrow focus of delivering credit to the provision of a wide range of financial services. In particular, one of the most successful MFIs, Grameen Bank, with the help of microcredit, has eliminated acute poverty for more than half the borrowers in Bangladesh, which amounts close to 50 million borrowers (Sarkar, 2008). Empirical evidence has shown that the success of this sector varied, as many MFIs have failed, while others have succeeded in serving millions of poorer people (Awaworyi Churchill \& Smyth, 2017). Initially, MFIs were designed to receive subsidies from governments to reflect their role of social assistance; however in 1990 's since the commercialising of MFIs, subsidies have been removed. According to Wagner and Winkler (2013), the commercialisation of MFIs has provided better results, whereby, as the MFIs have, once released from receiving subsidies, initiated many banking products that have started to generate income.

MFIs are now acknowledged to be an integral part of the financial system. Since the early 1990s, studies focusing on the efficiency of various financial institutions have become even more important (Berger \& Humphrey, 1997). The commercialisation of MFIs has led to a growing amount of literature focussing on MFIs financial performance to examine their sustainability. On the other hand, there are only a limited number of studies which have investigated the effectiveness of the dual aspects of MFIs, namely; their social and financial effectiveness (Armendáriz \& Szafarz, 2011). Although the issue that MFIs need to both strive for financial sustainability, as well as preserving their 
social objective to eradicate poverty has been well known, it has not received significant attention by researchers (Zainal, Md Nassir, Kamarudin, \& Law, 2020). In essence, MFIs may lose sight of their social mission when they concentrate on achieving financial sustainability. Therefore, this research is highly meaningful, as it compares the level of MFIs social efficiency by measuring the outreach of MFIs to the poor, while at the same time measuring MFIs' financial efficiency, as an indicator on their sustainability and ability to remain viable in the industry, hence, reducing poverty.

Next, the effects of bank regulation and supervision on the efficiency of MFIs were studied. Since the operation of MFIs, the advent of commercialisation has involved taking money from the public. Thus, MFIs are obligated to be governed and regulated under banking regulatory frameworks. According to the Microfinance Industry Report, 2010, all forms of regulated microfinance are governed by the banking regulators of their respective country. Such bank regulation comprises of two components, while another two components fall under the category of bank supervision. First is the restrictions on banking activities $(l b a)$ that put specific limitations on banking activities. This also involves securities investments, insurance and investments in real estate (Barth, Brumbaugh, \& Wilcox, 2000). Second is the details of capital regulation requirements $(\mathrm{Icr})$ that indicate the minimum amount of liquid capital that banks are required to keep in hand to serve as a safeguard for any unpredicted failures and losses that need to be borne by the banks (Barth, Lin, Ma, Seade, \& Song, 2013). Third is the bank supervisory power (Ipsr) that explains the capability of any institutional supervisors who are involved in banking decisions (Klomp \& de Haan, 2012). Last is the independence of the banking supervisors (lisp) which measures the level of independence of the supervisory authority from intervention by governments that is legally secured from the banking industry (Barth, Nolle, Phumiwasana, \& Yago, 2003).

Several studies have examined the impact of bank regulation and supervision within the formal banking sector, while a more limited number of studies have been carried out on the MFI industry. It is somewhat surprising that more studies of MFIs have not been carried out, as MFIs are now an integral part of the financial system and the operation of MFIs involves banking products. However, MFIs still preserve their social aspect, which is to eradicate poverty. Understanding how MFIs cope with such dual needs (social and financial), while being governed under a similar set of banking regulations is vital, to ensure there is no bias, especially when MFIs continue to preserve their social mission of poverty reduction. This research investigated and determined the level of social and financial efficiency among selected MFIs in Southeast Asian region as its first objective. Second, this research examined to what extent internal (i.e. firms' characteristics) and external factors (i.e. macroeconomic conditions) influenced the level of social and financial efficiency of the selected MFIs. Third, the results were further investigated to examine the effect of bank regulation and supervision on the level of social and financial efficiency of the selected MFIs.

The remainder of this study is organised as follows. Section 2 discusses the existing theoretical frameworks and also reviews the existing literature on the performance of MFIs and the impact of bank regulation and supervision on MFIs. Section 3 develops the estimation models and methods to fulfil the objectives of this study. Meanwhile, in Section 4, the findings of the analysis on the impact of bank regulation and supervision 
on the level of social and financial efficiency of MFIs are presented. Lastly, Section 5 delivers both a summary and conclusions to the present study.

\section{Literature Review}

Introduced by Banker, Charnes and Cooper (1984) and Charnes, Cooper and Rhodes (1978), data envelopment analysis (DEA) has become a globally accepted method, which is used by both academicians and practitioners as a methodology to evaluate the performance of financial institutions. However, extensive empirical evidence already exists on the level of efficiency in the MFI industry (Bassem, 2014; Haq, Skully, \& Pathan, 2010; Mia \& Chandran, 2016; Wijesiri, Yaron, \& Meoli, 2015). The primary goal of social outreach for MFIs is poverty reduction. The benefits of the MFI's social goals are disseminated to poor communities through the various financial services offered by MFIs. Previous literature has determined that the social goal of MFIs is determined by the social value of output produced by MFIs. This comprises of six aspects, namely, cost to users, worth to users, depth, breadth, length and scope (Schreiner, 2002). Among the approaches in this area, each of which has been extensively investigated, the present study chose to focus on the depth and breadth of outreach to measure the level of social efficiency of the selected MFIs (Quayes, 2012). Depth were needed to consistently measure the ability of MFIs to penetrate deeply to the poorest in society, while breadth was defined as the number of poor borrowers that have been served by the selected MFIs.

Meanwhile, a growing amount of literature has discussed the aspect of financial efficiency (Awaworyi Churchill, Korankye Danso, \& Nyatefe, 2018; Cull, Demirgüç-Kunt, \& Morduch, 2011; Hermes \& Lensink, 2011; Kaur, 2016). The critical contribution of these works is the solution that they provide for MFIs to be financially stable while continuing to provide continuous financial services to poorer people. Therefore, the importance of reducing poverty remains a prime consideration as it is the crucial role of MFIs. According to Roy and Goswami (2013), unlike banking institutions, MFIs concentrate on profitability, simply for financial sustainability. This indirectly indicates the ability of MFIs to generate income and no longer depends on subsidies to operate their businesses.

On the other hand, the empirical evidence regarding MFIs in Southeast Asian countries has been limited to their dual performance (social and financial). To date, the studies by Bédécarrats, Baur and Lapenu (2012), Vanroose and D’Espallier (2013), and Widiarto and Emrouznejad (2015) have been debated by researchers as the most considerable bodies of empirical research, which have been performed to examine the level of social and financial efficiency of MFIs in Southeast Asian countries. Some of these studies sought to examine the impact of the development of the formal financial sector toward the social and financial performance of MFIs. By applying the number of active borrowers and operational self-sustainability as proxy to social outreach and financial sustainability, they suggested that MFIs gained more profit when there was less access to poor borrowers. The implication of this showed the relative involvement of high transaction costs that gradually affected the reduced profitability of MFIs when providing small loans to the poor. Widiarto and Emrouznejad (2015) employed the DEA 
method to examine both the financial and social efficiency levels between conventional and Islamic MFIs. They discovered that there was higher financial efficiency in conventional MFIs, as compared to a lower level of social efficiency in Islamic MFIs. They suggested that conventional MFls were well established and had the advantage of economies of scale while Islamic MFIs were still in the infancy stage in the market and that there was still room for improvement.

The introduction of financial regulation was expected to improve the operation MFIs in developing countries. The transformation from their original state of unregulated financial institutions into regulated financial institutions would allow them to avoid considerable exposure, which is a lesson learned when providing banking products and services (Harstaka \& Nadolnyak, 2007). Studies on the impact of bank regulation and supervision on the levels of social and financial efficiency that explored the factors that influence the performance of MFIs are very limited. Among them, there is an emerging body of evidence that has indicated that regulation costs affected the financial performance of MFIs in Ghana (Steel \& Andah, 2003). Also, Cull, DemirgüçKunt and Morduch (2011) indicated that regulation of microfinance institutions provided a negative impact on profitability. Based on Harstaka and Nadolnyak (2007), regular banking regulations do not apply to MFIs activities as a whole. This issue of being governed under a similar set of regulations and supervision as commercial banks provide an unbalanced condition, especially for MFIs. However, these issues have been extensively investigated in attempts to prove how regulation and supervision impact the efficiency of commercial banks (Barth, Caprio, \& Levine, 2004).

On restrictions of banking activities ( $l b a)$, according to Barth et al. (2013), there was much evidence regarding their negative impact on bank efficiency whereby the restrictions led to limitations to commercial bank operations. However, the study by Gaganis and Pasiouras (2013) suggested a few techniques for improvement including controlling and monitoring activities to assist the banks to focus on their business operations, and thus, enhancing revenue for the banks. Meanwhile, a study by Barth et al. (2013) showed a significant positive association between restrictions on the capital regulation requirement $(/ c r)$ and banking efficiency. However, strict capital regulations that exist in a weak form may lower the risk for banks, but they do not necessarily increase their efficiency level. On the contrary, the study by Gaganis and Pasiouras (2013) proved there was evidence to suggest that limits on the number of loan disbursement to the clients from an increase in capital requirements may lower the amount available for banks lending activities.

Official banking supervisory power (Ipsr) was positively associated with the efficiency of the banks (Barth et al., 2013). This referred to the expertise and ability of bank supervisors to handle market failures. Contrary to Barth et al. (2013), Alam (2013) found conflicts among the boards of directors who ran businesses when they were involved in company decision making. Moreover, the independence of banking supervisors (lisp) has encouraged them to focus on the performance of banks, while avoiding government intervention (Barth et al., 2013). However, with less intervention from a third party (government), Gaganis and Pasiouras (2013) provided insightful observation into the mechanisms leading to misconduct, where banking supervisors tended to focus less on bank performance but to serve their personal interests. 
In summary, the above literature has revealed the following research gaps. First, the majority of the reviewed research has concentrated on the Asian region and has focused on the performance of MFIs, in terms of their social and financial sustainability. On the other hand, several studies have examined social efficiency as a measurement of poverty reduction by MFIs. Second, a limited number of studies have examined the firms' characteristics (internal) and macroeconomic conditions (external) as determinants of the level of social and financial efficiency, especially in the Southeast Asian region. Third, several empirical studies have examined the impact of bank regulation and supervision on the efficiency of commercial banks, but not from the context of the MFI industry. The glitches caused are particularly noticeable, especially when little empirical evidence is available regarding the impact of bank regulation and supervision, particularly from the perspective of the social and financial performance of MFIs. The present study, therefore, has attempted to fill a demanding gap in the existing literature by providing new empirical evidence on MFIs operating in the Southeast Asian region concerning the impact of bank regulation and supervision on their levels of social and financial efficiency.

\section{Data and Research Methodology}

The database of MFls used in this study was extracted from the Microfinance Information Exchange (MIX) (Vanroose \& D'Espallier, 2013; Widiarto \& Emrouznejad, 2015). The sample consisted of data from five countries, namely; Indonesia, Cambodia, Malaysia, the Philippines and Thailand, from the Southeast Asian region. In line with Porvazník, Vydrová and Ljudvigová (2017), the main reason that these countries were considered in the estimation was that they are developing countries with sizeable poor populations and have a high number of MFls. The sample used in this study comprised $172 \mathrm{MFIs}$, each possessing a 3 to 5 diamond rating between the years 2012 to 2018. Besides, the macroeconomic data used in this study were collected from the World Bank's World Development Indicators (WDI), while the data on banking regulations were selected from a survey on Bank Regulation and Supervision carried out by the World Bank (Barth et al., 2004; 2013).

\subsection{First Stage Analysis - Data Envelopment Analysis (DEA)}

To estimate the input-oriented technical efficiency of the selected MFIs, the present study employed non-parametric data envelopment analysis (DEA) incorporating the variable returns to scale (VRS) model. The VRS model assumptions deliver an overall efficiency (TE) score which comprises scale efficiency (SE) and pure technical efficiency (PTE). The SE determines the right size to operate by each decision-making unit (DMU). Meanwhile, the PTE indicates the DMU from the aspect of managerial efficiency, without considering the scale of operation. Therefore, the VRS assumptions deliver more consistent results on the efficiency of a DMU, as opposed to the constant returns to scale (CRS) model (Sufian, 2009; Zainal et al., 2019). In the present study, the TE score indicated the level of social and financial efficiency of the selected MFIs. 
There are two common approaches in basic non-parametric DEA models. These are the input-oriented approach which holds the output constant while maximising the utilisation of inputs, and the output-oriented approach which keeps the input constant, while at the same time maximising the output production. In the present study, the input-oriented DEA analysis was employed to attain the best measurement of productivity (Ruch, 1982), as can be seen in the following Equation (1):

$\theta *=\operatorname{Min} \theta$

Subject to:

$$
\begin{array}{ll}
\sum_{j=1}^{n} \lambda_{j} y_{r j} \geq y_{r} & r=1,2, \cdots, s \\
\sum_{j=1 n}^{n} \lambda_{j} y_{i j} \leq \theta x_{i o} & i=1,2, \ldots, m ; \\
\sum_{j=1} \lambda_{j}=1 & \lambda_{j} \geq 0, j=1,2, \ldots, n
\end{array}
$$

This study undertook the production approach to determine the level of social and financial efficiency of the selected MFIs. The production approach was most appropriate due to the nature of MFIs that fully utilise capital and labour as inputs to produce outputs in terms of deposits, loans and other financial products (Kamarudin, Sufian, \& Nassir, 2016; Kamarudin, Zack, Sufian, \& Anwar, 2017; Saw, Kamarudin, \& Latiff, 2020;

Table 1. Descriptive statistics of the input and output variables for social and financial efficiency in the selected MFIs

\begin{tabular}{lrrrr}
\hline Variables & Minimum & Maximum & Mean & $\begin{array}{r}\text { Standard } \\
\text { deviation }\end{array}$ \\
\hline Inputs of MFIs & & & & \\
Social efficiency and Financial efficiency & & & & \\
Operating expense (million USD) & 0.01 & 166 & 4.01 & 12.10 \\
Assets (million USD) & 0.01 & 4821 & 61.30 & 302 \\
Personnel (million USD) & 0.01 & 98 & 2.12 & 6.30 \\
Outputs of MFIs & & & & \\
Social efficiency & & & & 1.34 \\
Average loan balance (GNI per capita) & 0.015 & 18.13 & 0.71 & \\
Poor borrower & 110 & 1671663 & 46343 & 134210.60 \\
Financial efficiency & & & & 30.10 \\
Revenue (million USD) & 0.01 & 463 & 8.12 & \\
\hline
\end{tabular}

Note: The input variables are similar for both social and financial efficiency. Source: MIX Market database (www.mixmarket.org). 
Sufian \& Kamarudin, 2014). Table 1 depicts the input and output variables for the level of social and financial efficiency of the selected MFIs.

\subsection{Second Stage Analysis - Panel Regression Analysis under the Generalized Method of Moments (GMM)}

This study continued its analysis by using panel dynamic regression analysis, incorporating the generalized method of moments (GMM) estimator. A study by Ngau, Bakri, Al Shami, Hamid and Zainal (2020) addressed the strong justification for using panel static regression analysis. However, there has been an ongoing issue regarding residuals which might be correlated across different firms (cross-sectional) and years for a given firm (time-series) (Assefa, Hermes, \& Meesters, 2013; Hussain, Slusarczyk, Kamarudin, Thaker, \& Szczepańska-Woszczyna, 2020; Vanroose \& D’Espallier, 2013). Furthermore, there is a chance that the explanatory variables are not strictly exogenous. If the explanatory variables are not strictly exogenous, this may violate the assumption of classical linear regression.

\subsection{Controlling for Potential Endogeneity}

To overcome these issues, the lagged explanatory variables in the model regression were used by undertaking the GMM estimator, as proposed by Arellano and Bond (1991) and Arellano and Bover (1995). The system GMM estimator (see, Blundell and Bond, 1998) deals with the endogeneity and persistence issues and therefore yields consistent estimates. In the system GMM estimator, the regression equations in levels and differences were join into a single system with a set of instrumental variables for each of them. Using this method, the present study explored the panel structure of the dataset and controlled for potential endogeneity problems of the explanatory variables, unobserved firm-specific effects, time-specific effects and the measurement of the lagged dependent variables.

The consistency of the econometric method used in this study relied mostly on the instrument validity, which was examined using the Hansen's test for overidentifying the restrictions, and the test is asymptotically distributed as $\chi 2$ in the number of restrictions. If the null hypothesis that the instruments were orthogonal to the errors is rejected, the test indicates that the estimations are not consistent (Baum, Caglayan, \& Talavera, 2010). The test statistics were also presented for the first and second-order of serial correlation in the error terms. In the context of a dynamic panel dataset, if the instruments are not correlated with the errors, then second-order serial correlation should not exist (Baum et al., 2010; Hussain, Kamarudin, Thaker and Salem, 2019). Table 2 depicts the details of the independent and dependent variables used in the regression analysis of the selected MFIs.

Thus, the general model used in this study was:

Social and Financial Efficiency ${ }_{i, t}=\alpha$ (Social@Financial Efficiency $\left.{ }_{i, t-1}\right)+$ $\beta_{i, t}\left(\sum\right.$ Bank Regulation $\left._{\mathrm{t}}\right)+\beta_{i, t}\left(\sum\right.$ Bank Supervision $\left._{t}\right)+\beta_{i, t}\left(\sum\right.$ Firm Characteristics $\left.{ }_{i, t}\right)+$

$\beta_{i, t}\left(\sum\right.$ Macroeconomic Conditions $\left._{t}\right)+\eta_{i}+\varepsilon_{i, t}$ 
Table 2. Descriptive statistics on bank regulation, firms' characteristics and macroeconomic conditions

\begin{tabular}{lccl}
\hline Variable & Mean & SD & Description \\
\hline $\begin{array}{l}\text { Dependent } \\
\text { Social efficiency (Isef) }\end{array}$ & 0.31 & 0.29 & $\begin{array}{l}\text { The score of social efficiency in DEA } \\
\text { Financial efficiency (Ifef) }\end{array}$ \\
\hline The score of financial efficiency in DEA
\end{tabular}

Note: The data were derived from the World Development Indicators (WDI) and the Survey of Bank Regulation and Supervision (World Bank, 2018a, 2018b).

\section{Results and Discussions}

\subsection{Social and Financial Efficiency Scores}

The first initiative of this study was to consider the 'rule of thumb' on the number of output and input variables, as proposed by Cooper, Seiford and Tone (2000). Hence, the number of DMUs in this study, which comprised 172 MFIs, was larger than the number of output and input variables in the social and financial efficiency model, $15(3 \times 2)$ and $15(3 \times 1)$. Thus, such a condition validified the selections of the variables, as it satisfied 
the 'rule of thumb'. This validated the output and input variables to measure the efficiency score for each of the DMUs.

Table 3 reveals the score of the level of social and financial efficiency attained from DEA analysis on the selected MFIs in Southeast Asian countries. The results also present the levels of PTE and SE as elements for both social and financial efficiency. Besides, the TE score demonstrated the full score for efficiency, in terms of the level of social and financial efficiency. Overall, the total score for social efficiency (Panel $\mathrm{H}$ of Table 3 ) was equal to $31.10 \%$ with a wastage input of $68.90 \%$ between 2012 to 2018 . The cause of higher input wastage was due to the inefficient management of the selected MFIs when

Table 3. Score of the level of social and financial efficiency of MFIs in Southeast Asian countries (2012-2018)

\begin{tabular}{|c|c|c|c|}
\hline Efficiency measures & $\begin{array}{c}\text { No. of } \\
\text { observations }\end{array}$ & $\begin{array}{l}\text { Social efficiency } \\
\text { (Mean) }\end{array}$ & $\begin{array}{c}\text { Financial efficiency } \\
\text { (Mean) }\end{array}$ \\
\hline \multicolumn{4}{|l|}{ Panel A: All Firms 2012} \\
\hline Technical efficiency & 172 & 0.292 & 0.701 \\
\hline Pure technical efficiency & 172 & 0.361 & 0.722 \\
\hline Scale efficiency & 172 & 0.845 & 0.895 \\
\hline \multicolumn{4}{|l|}{ Panel B: All Firms 2013} \\
\hline Technical efficiency & 172 & 0.256 & 0.681 \\
\hline Pure technical efficiency & 172 & 0.402 & 0.751 \\
\hline Scale efficiency & 172 & 0.755 & 0.908 \\
\hline \multicolumn{4}{|l|}{ Panel C: All Firms 2014} \\
\hline Technical efficiency & 172 & 0.278 & 0.651 \\
\hline Pure technical efficiency & 172 & 0.341 & 0.721 \\
\hline Scale efficiency & 172 & 0.78 & 0.912 \\
\hline \multicolumn{4}{|l|}{ Panel D: All Firms 2015} \\
\hline Technical efficiency & 172 & 0.291 & 0.677 \\
\hline Pure technical efficiency & 172 & 0.342 & 0.815 \\
\hline Scale efficiency & 172 & 0.792 & 0.911 \\
\hline \multicolumn{4}{|l|}{ Panel E: All Firms 2016} \\
\hline Technical efficiency & 172 & 0.101 & 0.655 \\
\hline Pure technical efficiency & 172 & 0.195 & 0.741 \\
\hline Scale efficiency & 172 & 0.744 & 0.921 \\
\hline \multicolumn{4}{|l|}{ Panel F: All Firms 2017} \\
\hline Technical efficiency & 172 & 0.298 & 0.695 \\
\hline Pure technical efficiency & 172 & 0.358 & 0.757 \\
\hline Scale efficiency & 172 & 0.793 & 0.929 \\
\hline \multicolumn{4}{|l|}{ Panel G: All Firms 2018} \\
\hline Technical efficiency & 172 & 0.267 & 0.701 \\
\hline Pure technical efficiency & 172 & 0.298 & 0.756 \\
\hline Scale efficiency & 172 & 0.707 & 0.922 \\
\hline \multicolumn{4}{|l|}{ Panel H: All Years } \\
\hline Technical efficiency & 1204 & 0.311 & 0.721 \\
\hline Pure technical efficiency & 1204 & 0.372 & 0.776 \\
\hline Scale efficiency & 1204 & 0.806 & 0.916 \\
\hline
\end{tabular}


maximising the utilisation of input resources, even though they operated at the right scale (where PTIE $=62.80 \%>$ SIE $=19.40 \%$ ). Likewise, the score of financial efficiency in the selected MFIs in Southeast Asian countries (Panel H of Table 3) was 72.10\%, with a lower wastage of input at $27.90 \%$ from 2012 to 2018. To gain financial efficiency, the amount of wastage in the input was generally too low, which was due to the inefficiency of the selected MFIs to manage fully the exploitation of input resources, although they were operating at an optimum scale (where PTIE $=22.40 \%>$ SIE $=8.40 \%$ ).

From the findings, it can be seen that the score of financial efficiency of $72.10 \%$ was higher, while the selected MFIs only attained a score of $31.10 \%$ for social efficiency. The score for social efficiency was found to be $41.00 \%$ lower than the score for financial efficiency. The results suggested that the selected MFIs in the Southeast Asian region between 2012 to 2018 were financially stable to provide banking operations over an extended period. In essence, the results also exposed that the selected MFIs recorded lower wastage to produce financial efficiency $(27.90 \%)$ but a higher amount of input wastage in generating social efficiency (68.90\%).

Also, a vital issue that needs to be addressed is that even though the essential goal of MFIs is to eliminate poverty, the selected MFIs only had a low score of social efficiency (31.10\%). This finding showed that even though the selected MFIs in the Southeast Asia region were stable to provide banking services in the long run, they were unable to contribute to poverty reduction, thus, implying that they offered no significant impact on the poor. On the other hand, it has provided evidence to suggest that the selected MFIs in the Southeast Asia region have shifted their focus from their original social mission (outreach) to becoming more concerned in accomplishing the goal of financial sustainability (Quayes, 2012).

The results from the parametric t-test in Table 4 suggested that the TE for social efficiency was lower than the TE for financial efficiency (where the TE $0.31<0.72$ ) for the selected MFIs and the results were significantly different at the $1 \%$ level. Likewise,

Table 4. Robustness tests for the score of the level of social and financial efficiency of MFIs in Southeast Asian countries (2012-2018)

\begin{tabular}{|c|c|c|c|c|c|c|}
\hline \multirow{3}{*}{ Test statistics } & \multirow{2}{*}{\multicolumn{2}{|c|}{$\begin{array}{c}\text { Parametric test } \\
\text { t-test } \\
t(\operatorname{Prb}>t)\end{array}$}} & \multicolumn{4}{|c|}{ Non-parametric test } \\
\hline & & & \multicolumn{2}{|c|}{$\begin{array}{c}\text { Mann-Whitney test } \\
Z(\operatorname{Pr} b>z)\end{array}$} & \multicolumn{2}{|c|}{$\begin{array}{l}\text { Kruskal-Wallis test } \\
\quad x 2(\operatorname{Pr} b>x 2)\end{array}$} \\
\hline & Mean & $\mathrm{t}$ & Mean rank & z & Mean rank & $x 2$ \\
\hline \multicolumn{7}{|c|}{ Technical efficiency } \\
\hline Social & 0.31 & $-47.72^{* * *}$ & 658.19 & $-33.70 * * *$ & 658.19 & $1021.97^{* * *}$ \\
\hline Financial & 0.72 & & 1720.16 & & 1720.16 & \\
\hline \multicolumn{7}{|c|}{ Pure technical efficiency } \\
\hline Social & 0.37 & $-41.61 * * *$ & 691.56 & $-32.43 * * *$ & 691.56 & $971.35^{* * *}$ \\
\hline Financial & 0.77 & & 1686.94 & & 1686.94 & \\
\hline \multicolumn{7}{|c|}{ Scale efficiency } \\
\hline Social & 0.81 & $-18.71^{* * *}$ & 911.43 & $-14.51^{* * *}$ & 911.43 & $257.58^{* * *}$ \\
\hline Financial & 0.92 & & 1404.59 & & 1404.59 & \\
\hline
\end{tabular}

Note: $* * *$ indicates significance at the $1 \%$ level. 
the PTE and SE for social efficiency also showed a lower mean, as compared to the PTE and SE for financial efficiency and were significantly different at the $1 \%$ level (where PTE $0.37<0.77$ and SE $0.81<0.92$ ). The findings from the parametric t-test were further confirmed by the non-parametric Kruskal-Wallis and Mann-Whitney tests. In short, the results of the study inferred that the selected MFIs in the Southeast Asian region achieved a significantly higher level of financial efficiency and a significantly lower level of social efficiency.

\subsection{The Determinants of Firms' Characteristics and Macroeconomic Conditions toward the Level of MFIs' Social and Financial Efficiency}

Tables 5 and 6 reveal the results of the significant relationship between firms' characteristics and the level of social and financial efficiency of the selected MFIs. The findings on the size $(I s)$ of the selected MFIs shows a significant negative relationship, which suggest that larger sized MFIs led to lower scores of efficiency. Based on the studies by Assefa et al. (2013), Laeven and Levine (2007) and Widiarto and Emrouznejad, (2015), the size of MFIs becomes larger when they start providing banking products, and this leads to the formation of complicated and tremendously more extensive entities, hence, providing difficulties for such MFIs to control and monitor themselves since they have become too large to easily manage, which will lead to a lower level of social and financial efficiency. Next, the age (la) of the operation appeared to be negatively associated with the level of social and financial efficiency of the selected MFIs. This implied that older MFIs do not possess sufficient skills to weather the fallout from global crises, as MFIs are nowadays recognised as an integral part of the financial market.

The findings also reported a positive and significant relationship between financial leverage (If) and both of the efficiencies of the selected MFIs (Tables 5 and 6). The result confirmed the theory of Modigliani and Miller (1958) regarding capital structure which proposed that a high percentage of debt financing would reduce the cost of capital, thus, producing high revenues for MFIs. Meanwhile, the regression coefficients of profitability $(I p)$ were found to be also significant and positively related to both of the efficiencies of the selected MFIs. This result proved that MFIs could adequately manage their assets to attain maximum profit (Lebovics, Hermes, \& Hudon, 2016; Wijesiri et al., 2015).

Concerning the impact of macroeconomic performance on the level of social and financial efficiency of the selected MFls, it can be seen from Tables 5 and 6 that the coefficient of economic growth $(I g d p)$ showed a significant positive sign. This suggested that economic growth encouraged economic activities among the poor, thus, reducing the risk associated with loan repayments. This study also revealed a negative and significant correlation between inflation (linf) and both of the efficiencies of the selected MFIs. According to the study by Bakri, Ismail, Zainal, Kamarudin and Shami (2020) and Zainal, Law, Md Nasir and Bakri (2020), a spike in general prices during a period of high inflation would give rise to a problematic situation for borrowers who needed to make loan repayments, as their higher living costs would increase, while their income remained constant. However, when referring to Table 6, value-added industry $(/ v d)$ recorded a positive and significant coefficient only with the financial efficiency of the selected MFIs. The findings suggested that the higher revenue from the 
microfinance industry has contributed to growth in the GDP. The improved economic condition leads to a stable and lower inflation rate and such a condition improves the performance of the whole banking system, including that of MFIs (Assefa et al., 2013; Vanroose \& D'Espallier, 2013). Finally, the coefficient of foreign direct investment (Ifd) appeared to be negatively significant in influencing the level of social and financial efficiency of the selected MFIs. The high involvement of FDI might influence the survival of MFIs. The growth of MFIs seems to be no longer sustainable with inflows of FDI. This is mainly because FDI inflows benefit technology advancement, large volume size and skilled labour where these conditions do not entail activities which require the support of MFls (Ahlin, Lin, \& Maio, 2011; Alaeddin, Altounjy, Zainudin, \& Kamarudin, 2018; Hermes, Lensik, \& Meesters, 2011).

\subsection{Does Bank Regulation and Supervision Influence the level of Social and Financial Efficiency of MFIs?}

Table 5 (Model 3a) discloses the significantly negative relationship between the restrictions on banking activities $(I b a)$ and the social efficiency of the selected MFIs, and this explains that more (less) restrictions on bank activities affected the selected MFIs by lowering (higher) the production of social efficiency. The lower social efficiency score was caused by more restrictions being imposed on the banking activities carried out by the selected MFIs, such as investments in securities, insurance and investments in real estate. The higher restrictions on these activities limited the income of the selected MFIs which could be reallocated to more loans for needy borrowers, thus, reducing the social outreach of the selected MFIs (Ahmad, 2011; Barth et al., 2013). However, when referring to Model $3 b$ in Table 6, the restrictions on banking activities ( $/ b a$ ) presented a significant positive relationship with the financial efficiency of the selected MFIs. This situation implied that greater restrictions on banking activities, such as insurance, investments in real estate and investments in securities led to an increase in the financial efficiency of the selected MFIs. This result was consistent with the studies by Gaganis and Pasiouras (2013) and Chortareas, Girardone and Ventouri (2012), where both inferred that monitored and controlled banking activities enhanced the revenue and reduced the risks for MFIs, hence, promoting their stability to operate in the long run.

Table 5 (Model 4a) and Table 6 (Model 4b) also revealed the results of the regulation on the level of capital requirements (Icr), which appeared to be hostile and significantly negative to the level of social and financial efficiency of the selected MFIs. The result suggested that a high level of restrictions on the capital requirements of MFIs would lower both of the efficiencies of the MFIs. According to the study conducted by Barth et al. (2013), higher charges on any capital requirements could avoid credit risks, as the capital serves as a protection for any unpredicted losses by banks. However, in practice, within the MFI industry, a larger minimum capital requirement limits the amount of available capital that MFIs can disburse as loans to poor borrowers. This will reduce the MFIs social efficiency, and hence, resulting in lower revenue which may ultimately lower the financial efficiency of MFIs.

Based on Models $5 a$ and $5 b$ in Tables 5 and 6, the coefficients for the power of the banking supervisors (Ipsr) disclosed a significantly positive relationship with both 
Table 5. Result of the GMM regression on social efficiency

\begin{tabular}{|c|c|c|c|c|c|c|}
\hline Variables & Model 1a & Model 2a & Model 3a & Model 4a & Model 5a & Model 6a \\
\hline Constant & $\begin{array}{l}-0.726^{* *} \\
(0.412)\end{array}$ & $\begin{array}{c}0.517 \\
(3.215)\end{array}$ & $\begin{array}{l}0.503^{* * *} \\
(2.168)\end{array}$ & $\begin{array}{l}-0.286 \\
(2.988)\end{array}$ & $\begin{array}{l}-0.498 \\
(6.113)\end{array}$ & $\begin{array}{c}0.576 \\
(48.621)\end{array}$ \\
\hline \multicolumn{7}{|c|}{ Firm Characteristic Variables } \\
\hline Ise $(t-1)$ & $\begin{array}{l}0.279 * * * \\
(0.031)\end{array}$ & $\begin{array}{l}0.295^{* * *} \\
(0.035)\end{array}$ & $\begin{array}{l}-0.315^{* * *} \\
(0.050)\end{array}$ & $\begin{array}{l}0.623^{* * *} \\
(0.044)\end{array}$ & $\begin{array}{l}0.552^{* * *} \\
(0.063)\end{array}$ & $\begin{array}{l}-0.537^{* * *} \\
(0.198)\end{array}$ \\
\hline Is & $\begin{array}{l}-0.311^{* * *} \\
(0.032)\end{array}$ & $\begin{array}{l}-0.164^{* * *} \\
(0.057)\end{array}$ & $\begin{array}{c}0.033 \\
(0.071)\end{array}$ & $\begin{array}{l}-0.322^{* * *} \\
(0.049)\end{array}$ & $\begin{array}{l}-0.071 \\
(0.041)\end{array}$ & $\begin{array}{c}0.721 \\
(0.611)\end{array}$ \\
\hline la & $\begin{array}{l}-0.062^{* * *} \\
(0.022)\end{array}$ & $\begin{array}{l}-0.171^{* *} \\
(0.057)\end{array}$ & $\begin{array}{l}-0.815^{* * *} \\
(0.173)\end{array}$ & $\begin{array}{l}-0.007 \\
(0.118)\end{array}$ & $\begin{array}{l}-0.308^{* *} \\
(0.112)\end{array}$ & $\begin{array}{l}-2.483^{* *} \\
(1.214)\end{array}$ \\
\hline If & $\begin{array}{l}0.516^{* * *} \\
(0.033)\end{array}$ & $\begin{array}{l}0.294^{* * *} \\
(0.068)\end{array}$ & $\begin{array}{c}0.280 \\
(0.219)\end{array}$ & $\begin{array}{l}0.512^{* * *} \\
(0.068)\end{array}$ & $\begin{array}{c}0.180^{*} \\
(0.121)\end{array}$ & $\begin{array}{c}0.512 \\
(1.130)\end{array}$ \\
\hline Ip & $\begin{array}{l}0.219 * * * \\
(0.022)\end{array}$ & $\begin{array}{l}0.296^{* * *} \\
(0.031)\end{array}$ & $\begin{array}{l}0.423^{* * *} \\
(0.134)\end{array}$ & $\begin{array}{l}0.247^{* * *} \\
(0.037)\end{array}$ & $\begin{array}{l}0.218^{* * *} \\
(0.045)\end{array}$ & $\begin{array}{l}0.924^{* * *} \\
(0.211)\end{array}$ \\
\hline
\end{tabular}

Macroeconomic Variables

Igdp

$\begin{array}{ccccc}0.686 & -9.371 & 2.234^{* * *} & 1.274^{*} & -2.614 \\ (0.512) & (4.716) & (0.766) & (0.792) & (10.893)\end{array}$

$\operatorname{linf}$

$\begin{array}{lllll}-0.325 * * * & -0.312 & -1.156 * * * & -0.891 * * * & -0.676\end{array}$

Ivd

(0.087)

(0.603)

(0.232) (0.212)

(1.092)

$\begin{array}{lllll}-0.534 & -7.559 & 2.408 & 0.552 & -4.232\end{array}$

$(0.329) \quad(3.317) \quad(0.897) \quad(1.101) \quad$ (11.603)

Ifd

$\begin{array}{lllll}-0.454 * * * & -0.389 * * * & -1.720 * * * & -0.480 * * * & -0.193\end{array}$

(0.012)

(0.133)

(0.219)

(0.092)

(0.447)

Bank Regulation

Iba

$-2.329 * * *$

(0.654)

Icr

(0.439)

Bank Supervision

Ipsr

2.455*

(1.544)

lisp

$-7.320^{*}$

(5.123)

Wald $x^{2}$

876.

$A R(1) p$-value

$$
0.178
$$

$921.000 * * *$

$478.221^{* * *} 189.000^{* * *}$

$\begin{array}{cc}421.070^{* * *} & 170.188^{* * *} \\ 0.198 & 0.375 \\ 0.178 & 0.51 \\ 0.829 & 0.397 \\ 1204 & 1204\end{array}$

$A R(2) p$-value

0.441

0.266

0.216

0.243

0.592

0.235

0.313

0.294

No. of Obs.

1204

1204

1204

1204

Note: $* * * * *, *$ indicate significance at the $1 \%, 5 \%$ and $10 \%$ levels, respectively. Figures in parentheses denote standard errors. 
Regulation, Supervision and Social and Financial Efficiency of Microfinance Institutions in ASEAN-5 Countries

Table 6. Result of the GMM regression on financial efficiency

\begin{tabular}{|c|c|c|c|c|c|c|}
\hline Variables & Model 1b & Model 2b & Model 3b & Model 4b & Model 5b & Model 6b \\
\hline Constant & $\begin{array}{l}0.712^{* * *} \\
-(0.078)\end{array}$ & $\begin{array}{c}-2.922^{*} \\
-(1.574)\end{array}$ & $\begin{array}{c}-2.729 * \\
-(1.477)\end{array}$ & $\begin{array}{c}-2.792 \\
-(2.921)\end{array}$ & $\begin{array}{l}-5.812^{* * *} \\
-(1.447)\end{array}$ & $\begin{array}{c}-2.203 \\
-(1.623)\end{array}$ \\
\hline \multicolumn{7}{|c|}{ Firm Characteristic Variables } \\
\hline $\operatorname{lfe}(t-1)$ & $\begin{array}{l}0.475^{* * *} \\
(0.066)\end{array}$ & $\begin{array}{l}0.512 * * * \\
(0.025)\end{array}$ & $\begin{array}{l}0.622^{* * *} \\
(0.075)\end{array}$ & $\begin{array}{l}0.451^{* * *} \\
(0.056)\end{array}$ & $\begin{array}{l}0.552^{* * *} \\
(0.072)\end{array}$ & $\begin{array}{l}0.588^{* * *} \\
(0.024)\end{array}$ \\
\hline Is & $\begin{array}{l}-0.059 * * * \\
(0.009)\end{array}$ & $\begin{array}{l}-0.033^{* * *} \\
(0.005)\end{array}$ & $\begin{array}{l}-0.043^{* * *} \\
(0.010)\end{array}$ & $\begin{array}{l}-0.034^{*} \\
(0.017)\end{array}$ & $\begin{array}{c}0.067 \\
(0.023)\end{array}$ & $\begin{array}{l}-0.042^{* * *} \\
(0.010)\end{array}$ \\
\hline la & $\begin{array}{l}-0.167^{* * *} \\
(0.004)\end{array}$ & $\begin{array}{l}-0.124 * * * \\
(0.005)\end{array}$ & $\begin{array}{l}-0.083^{* * *} \\
(0.012)\end{array}$ & $\begin{array}{l}-0.131 * * * \\
(0.042)\end{array}$ & $\begin{array}{c}0.008 \\
(0.025)\end{array}$ & $\begin{array}{l}-0.127^{* * *} \\
(0.015)\end{array}$ \\
\hline If & $\begin{array}{l}0.161^{* * *} \\
(0.007)\end{array}$ & $\begin{array}{l}0.091^{* * *} \\
(0.027)\end{array}$ & $\begin{array}{l}0.114^{* * *} \\
(0.055)\end{array}$ & $\begin{array}{l}0.087^{* * *} \\
(0.036)\end{array}$ & $\begin{array}{l}-0.128^{* * *} \\
(0.021)\end{array}$ & $\begin{array}{l}0.084^{* * *} \\
(0.020)\end{array}$ \\
\hline Ip & $\begin{array}{l}0.062^{* * *} \\
(0.005)\end{array}$ & $\begin{array}{l}0.043^{* * *} \\
(0.080)\end{array}$ & $\begin{array}{c}0.019 \\
(0.020)\end{array}$ & $\begin{array}{l}0.038^{* *} \\
(0.022)\end{array}$ & $\begin{array}{l}-0.029 \\
(0.030)\end{array}$ & $\begin{array}{l}0.031^{* * *} \\
(0.015)\end{array}$ \\
\hline $\begin{array}{l}\text { Macroeco } \\
\text { Igdp }\end{array}$ & ables & $\begin{array}{c}0.514 \\
(0.217)\end{array}$ & $\begin{array}{c}0.374 \\
(0.261)\end{array}$ & $\begin{array}{c}0.198 \\
(0.624)\end{array}$ & $\begin{array}{c}0.642 * * \\
(0.278)\end{array}$ & $\begin{array}{c}0.562 \\
(0.378)\end{array}$ \\
\hline $\operatorname{linf}$ & & $\begin{array}{l}-0.077^{*} \\
(0.045)\end{array}$ & $\begin{array}{l}-0.178^{* * *} \\
(0.064)\end{array}$ & $\begin{array}{l}-0.264^{* *} \\
(0.102)\end{array}$ & $\begin{array}{l}-0.068^{*} \\
(0.045)\end{array}$ & $\begin{array}{l}-0.052^{*} \\
(0.021)\end{array}$ \\
\hline Ivd & & $\begin{array}{l}0.710^{* * *} \\
(0.241)\end{array}$ & $\begin{array}{l}0.681^{* *} \\
(0.292)\end{array}$ & $\begin{array}{l}1.112^{* * *} \\
(0.321)\end{array}$ & $\begin{array}{l}0.761^{* * *} \\
(0.218)\end{array}$ & $\begin{array}{c}0.566^{* *} \\
(0.279)\end{array}$ \\
\hline Ifd & & $\begin{array}{l}-0.008 \\
(0.018)\end{array}$ & $\begin{array}{l}-0.044^{* *} \\
(0.020)\end{array}$ & $\begin{array}{l}-0.048^{* * *} \\
(0.014)\end{array}$ & $\begin{array}{l}-0.026^{* * *} \\
(0.018)\end{array}$ & $\begin{array}{l}-0.012 \\
(0.015)\end{array}$ \\
\hline
\end{tabular}

Regulation and Supervision

Iba

$0.251 * * *$

(0.086)

Icr

$-0.346 * *$

(0.174)

Bank Supervision

Ipsr

$0.818^{* * *}$

(0.263)

lisp

0.079**

(0.032)

Wald $\mathrm{x}^{2}$

\begin{tabular}{cccccc}
$170.423^{* * *}$ & $387.168^{* * *}$ & $351.668^{* * *}$ & $214.114^{* * *}$ & $172.471^{* * *}$ & $489.156^{* * *}$ \\
0.006 & 0.004 & 0.002 & 0.018 & 0.020 & 0.005 \\
0.512 & 0.624 & 0.718 & 0.442 & 0.902 & 0.658 \\
0.421 & 0.169 & 0.722 & 0.717 & 0.418 & 0.196 \\
1204 & 1204 & 1204 & 1204 & 1204 & 1204 \\
\hline
\end{tabular}

$A R(1) p$-value

$\operatorname{AR}(2) p$-value

Hansen $p$-value

1204

Note: $* * * * *, *$ indicate significance at the $1 \%, 5 \%$ and $10 \%$ levels, respectively. Figures in parentheses denote standard errors. 
the efficiencies of the selected MFIs. The findings showed that the extra power of banking supervisors increased the level of social and financial efficiency of the selected MFIs. The results suggested that a higher efficiency score could be achieved as a result of regular monitoring by banking supervisors, mainly by preventing managers from misconduct and to discourage any excessive risk-taking behaviour. Besides, despite focusing on minimising losses and maximising profits, banking supervisors also seek to achieve outreach by instructing MFIs to issue more loans to poor borrowers while at the same time encouraging MFIs to undertake profit-generating activities (Barth et al., 2013; Alam, 2013).

Model $6 a$ in Table 5 revealed that the independence of the banking supervisor (lisp) was significant and negatively related to the social efficiency of the selected MFIs. However, the relationship was only significant at the $10 \%$ level and required cautious explanation. This suggested that the intervention of governments or any legislative bodies may lead banking supervisors to focus their interest on monetary goals rather than to encourage better outreach (social efficiency) by MFIs. This situation implied that MFIs may have left their original mission of poverty eradication. These results delivered a similar finding to Gaganis and Pasiouras (2013) who found that the greater independence of banking supervisors led to a negative impact on bank efficiency. However, the findings from Table 6 (Model $6 \mathrm{~b}$ ) indicated that the independence of banking supervisors (lisp) was positively significant in influencing the score of the financial efficiency of the selected MFIs. This indicated that greater independence of banking supervisors improved the production of financial efficiency in the selected MFIs. The result was consistent with the findings from Barth et al. (2013) who proposed that more independence for banking supervisors led to improved financial performance, as in recent times MFIs are considered as one of the regular components in the financial system.

\section{Conclusions and Recommendations}

The findings of this study were compatible with the original mission of MFIs, which was to eradicate poverty. However, the selected MFIs only managed to achieve a low level of social efficiency. The results of this study suggested that additional research was justified, due to the implication that the MFIs in Southeast Asian countries have been more focused on achieving financial sustainability, as compared to their original mission of reducing poverty. MFIs need to generate funds by offering banking products when governments no longer subsidise them, due to the advent of commercialisation. Unfortunately, the original mission of MFIs in their social effort of poverty eradication has received less focus while they have tended to focus more on achieving financial sustainability to remain viable in the long run. This has caused the MFIs in Southeast Asian countries to become inconsistently aligned to their original mission as they have attempted to balance their social and financial performance.

Besides that, this study found that the factors of the macroeconomic conditions and firm characteristics appeared to have a significant and variable impact on both the social and financial aspects of MFIs in Southeast Asian countries. This study also revealed a significant impact on both the level of social and financial efficiency of MFIs from bank regulation and supervision. The results revealed a significantly negative 
association which was observed between the restrictions on banking activities, capital regulation requirements and the independence of banking supervisors with the selected MFI's social efficiency. Meanwhile, the regression results showed that only the capital regulation requirements presented a negative correlation, while the other variables had a significant positive correlation with financial efficiency. Thus, in general, both components of bank regulation negatively influenced social efficiency while both components of bank supervision had a significantly positive impact on the financial efficiency of the selected MFIs.

In short, bank regulation and supervision are more applicable to banking activities with a profit motive, which is the main focus of commercial banks. This situation was proven by the findings of diminished social outreach and the improvement in the financial aspects of the selected MFIs. Most of the effort of this research has concentrated on the aspect of reducing poverty. Thus, this study could have introduced biasedness in the context of MFIs as banking regulations tend to concentrate on banking activities which generate revenue, often ignoring the social efforts which remain the core focus of MFIs.

This effect may have important implications for the regulators, and MFIs' management and investors in Southeast Asian countries. Regulators or policymakers could establish new regulatory frameworks which fulfil the dual needs (social and financial) of MFIs. Although MFIs currently deliver similar functions to commercial banks, they need to maintain their original mission in retaining their social objective. These results provide valuable new insights and guidance for the management of MFIs who seek to be both socially and financially efficient while achieving the dual goals of reaching out to the poor and operating sustainably in the long run. Future studies might be useful to examine the aspects of other outstanding issues, such as country governance and the level of competititon which might influence the social and financial aspects of MFIs.

\section{References}

Ahlin, C., Lin, J., \& Maio, M. (2011). Where does microfinance flourish? Microfinance institution performance in macroeconomic context. Journal of Development Economics, 95(2), 105-120. https://doi.org/10.1016/j.jdeveco.2010.04.004

Ahmad, U. (2011). Efficiency analysis of microfinance institutions in Pakistan (MPRA Paper, No. 34215). Munich, Germany: Munich University Library. Retrieved from https://mpra.ub.unimuenchen.de/34215/1/MPRA_paper_34215.pdf

Alaeddin O., Altounjy, R., Zainudin Z., \& Kamarudin, F. (2018). From physical to digital: Investigating consumer behaviour of switching to mobile wallet. Polish Journal of Management Studies, 17(2), 18 -30. https://doi.org/10.17512/pjms.2018.17.2.02

Alam, N. (2013). Impact of banking regulation on risk and efficiency in Islamic banking. Journal of Financial Reporting and Accounting, 11(1), 29-50. https://doi.org/10.1108/JFRA-03-20130010

Arellano, M., \& Bond, S. (1991). Some tests of specification for panel data: Monte Carlo evidence and an application for employment equations. Review of Economic Studies, 58(2), 277-297. https://doi.org/10.2307/2297968

Arellano, M., \& Bover, O. (1995). Another look at the instrumental variables estimation of error components models. Journal of Econometrics, 68(1), 29-51. https://doi.org/10.1016/03044076(94)01642-D 
Armendáriz, B., \& Szafarz, A. (2011). On mission drift in microfinance institutions. In B. Armendáriz \& M. Labie (Eds.), The handbook of microfinance (pp. 341-366). Singapore: World Scientific. https://doi.org/10.1142/9789814295666_0016

Assefa, E., Hermes, N., \& Meesters, A. (2013). Competition and the performance of microfinance institutions. Applied Financial Economics, 23(9), 767-782. https://doi.org/10.1080/09603107. 2012.754541

Awaworyi Churchill, S., Korankye Danso, J., \& Nyatefe, E. (2018). Microfinance institution performance: Does the macroeconomy matter? Economic Papers, 37(4), 429-442. https://doi. org/10.1111/1759-3441.12233

Awaworyi Churchill, S., \& Smyth, R. (2017). Ethnic diversity and poverty. World Development, 95(July), 285-302. https://doi.org/10.1016/j.worlddev.2017.02.032

Bakri, M.H., Ismail, S., Zainal, N., Kamarudin, F., \& Al Shami, S.(2020). Factors influencing spread in Malaysia securitisation market. Accounting, 6(4), 433440. https://doi.org/10.5267/j. ac.2020.4.0016

Banker, R.D., Charnes, A., \& Cooper, W.W. (1984). Some models for estimating technical and scale inefficiencies in data envelopment analysis. Management Science, 30(9), 1078-1092. https:// doi.org/10.1287/mnsc.30.9.1078

Barth, J.R., Brumbaugh, R.D., \& Wilcox, J.A. (2000). Policy watch: The repeal of Glass-Steagall and the advent of broad banking. Journal of Economic Perspectives, 14(2), 191-204. https://doi. org/10.1257/jep.14.2.191

Barth, J.R., Nolle, D.E., Phumiwasana, T., \& Yago, G. (2003). A cross-country analysis of the bank supervisory framework and bank performance. Financial Markets, Institutions \& Instruments, 12(2), 67-120. https://doi.org/10.1111/1468-0416.t01-2-00001

Barth, J.R., Caprio, G., \& Levine, R. (2004). Bank regulation and supervision: What works best? Journal of Financial Intermediation, 13(2), 205-248.

Barth, J.R., Lin, C., Ma, Y., Seade, J., \& Song, F.M. (2013). Do bank regulation, supervision and monitoring enhance or impede bank efficiency? Journal of Banking \& Finance, 37(8), 28792892. https://doi.org/10.1016/j.jbankfin.2013.04.030

Bassem, B.S. (2014). Total factor productivity change of MENA microfinance institutions: A Malmquist productivity index approach. Economic Modelling, 39(April), 182-189. https://doi. org/10.1016/j.econmod.2014.02.035

Baum, C.F., Caglayan, M., \& Talavera, O. (2010). On the sensitivity of firms' investment to cash flow and uncertainty. Oxford Economic Papers, 62(2), 286-306. https://doi.org/10.1093/oep/ gpp015

Bédécarrats, F., Baur, S., \& Lapenu, C. (2012), Combining social and financial performance: A paradox? Enterprise Development and Microfinance, 23(3), 241-258. https://doi.org/ 10.3362/1755-1986.2012.024

Berger, A.N., \& Humphrey, D.B. (1997). Efficiency of financial institutions: International survey and directions for future research. European Journal of Operational Research, 98(2), 175-212. https://doi.org/10.1016/S0377-2217(96)00342-6

Blundell, R., \& Bond, S. (1998). Initial conditions and moment restrictions in dynamic panel data models. Journal of Econometrics, 87(1), 115-143. https://doi.org/10.1016/S03044076(98)00009-8

Charnes, A., Cooper, W.W., \& Rhodes, E. (1978). Measuring the efficiency of decision-making units. European Journal of Operational Research, 2(6), 429-444. https://doi.org/10.1016/ 0377-2217(78)90138-8

Chortareas, G.E., Girardone, C., \& Ventouri, A. (2012). Bank supervision, regulation, and efficiency: Evidence from the European Union. Journal of Financial Stability, 8(4), 292-302. https://doi. org/10.1016/j.jfs.2011.12.001 
Cooper W.W., Seiford, L.M., Tone, K. (2000). Data envelopment analysis: A comprehensive text with models, applications, references and DEA-Solver software. Dordrecht, Netherlands: Kluwer Academic Publishers.

Cull, R., Demirgüç-Kunt, A., \& Morduch, J. (2011). Does regulatory supervision curtail microfinance profitability and outreach? World Development, 39(6), 949-965. https://doi. org/10.1016/j.worlddev.2009.10.016

Gaganis, C., \& Pasiouras, F. (2013). Financial supervision regimes and bank efficiency: International evidence. Journal of Banking \& Finance, 37(12), 5463-5475. https://doi.org/10.1016/ j.jbankfin.2013.04.026

Haq, M., Skully, M., \& Pathan, S. (2010). Efficiency of microfinance institutions: A data envelopment analysis. Asia-Pacific Financial Markets, 17(1), 63-97. https://doi.org/10.1007/s10690009-9103-7

Hartarska, V., \& Nadolnyak, D. (2007). Do regulated microfinance institutions achieve better sustainability and outreach? Cross-country evidence. Applied Economics, 39(10), 1207-1222. https://doi.org/10.1080/00036840500461840

Hussain, H.I., Kamarudin, F., Thaker, H.M.T., \& Salem, M.A. (2019). Artificial Neural Network to model managerial timing decision: Non-linear evidence of deviation from target leverage. International Journal of Computational Intelligence Systems, 12(2), 1282 -1294. https://doi. org/10.2991/ijcis.d.191101.002

Hussain, H.I., Slusarczyk, B., Kamarudin, F., Thaker, H.M.T., \& Szczepańska-Woszczyna, K. (2020). An investigation of an Adaptive Neuro-Fuzzy Inference System to predict the relationship among energy intensity, globalization, and financial development in major ASEAN Economies. Energies 13(4), Article 850. https://doi.org/10.3390/en13040850

Hermes, N., \& Lensink, R. (2011). Microfinance: Its impact, outreach, and sustainability. World Development, 39(6), 875-881. https://doi.org/10.1016/j.worlddev.2009.10.021

Hermes, N., Lensink, R., \& Meesters, A. (2011). Outreach and efficiency of microfinance institutions. World Development, 39(6), 938-948. https://doi.org/10.1016/j.worlddev.2009.10.018

Kamarudin, F., Sufian, F., \& Nassir, A.M. (2016). Does country governance foster revenue efficiency of Islamic and conventional banks in GCC countries? EuroMed Journal of Business, 11(2), 181-211. https://doi.org/10.1108/emjb-06-2015-0026

Kamarudin, F., Zack, H.C., Sufian, F. \& Anwar, N.A.M. (2017). Does productivity of Islamic banks endure progress or regress? Empirical evidence using Data Envelopment Analysis based Malmquist Productivity Index. Humanomics, 33(1): 84-118. https://doi.org/10.1108/h-082016-0059

Kaur, P. (2016). Efficiency of microfinance institutions in India: Are they reaching the poorest of the poor? Vision: The Journal of Business Perspective, 20(1), 54-65. https://doi.org/ $10.1177 / 0972262916628988$

Klomp, J., \& de Haan, J. (2012). Banking risk and regulation: Does one size fit all? Journal of Banking \& Finance, 36(12), 3197-3212. https://doi.org/10.1016/j.jbankfin.2011.10.006

Laeven, L., \& Levine, R. (2007). Is there a diversification discount in financial conglomerates? Journal of Financial Economics, 85(2), 331-367. https://doi.org/10.1016/j.jfineco.2005. 06.001

Lebovics, M., Hermes, N., \& Hudon, M. (2016). Are financial and social efficiency mutually exclusive? A case study of Vietnamese microfinance institutions. Annals of Public and Cooperative Economics, 87(1), 55-77. https://doi.org/10.1111/apce.12085

Mia, M.A., \& Chandran, V.G.R. (2016). Measuring financial and social outreach productivity of microfinance institutions in Bangladesh. Social Indicators Research, 127(2), 505-527. https:// doi.org/10.1007/s11205-015-0979-5

Microfinance Information Exchange. (n.d.). MIX Market Database 2018. Retrieve from https:// www.themix.org/ 
Microfinance Industry Report. (2010). GTZ ProMiS in collaboration with the Banking With The Poor Network. German Technical Cooperation, Promotion of the Microfinance Sector, Colombo, Sri Lanka.

Modigliani, F., \& Miller, M.H. (1958). The cost of capital, corporation finance, and the theory of investment. American Economic Review, 48(June), 261-297.

Ngau, D.S., Bakri, M.H., Al Shami, S.A., Hamid, B.A., \& Zainal, N. (2020). Determinants contributing to the primary market spread of securitisation in Malaysia. International Journal of Innovation, Creativity and Change, 11(12), 137-148.

Porvazník, J., Vydrová, J., \& Ljudvigová, I. (2017). The importance of holistic managerial competence and social maturity in human crisis. Polish Journal of Management Studies, 15(1), 163-173. https://doi.org/10.17512/pjms.2017.15.1.16

Quayes, S. (2012). Depth of outreach and financial sustainability of microfinance institutions. Applied Economics, 44(26), 3421-3433. https://doi.org/10.1080/00036846.2011.577016

Roy, A., \& Goswami, C. (2013). A scientometric analysis of literature on performance assessment of microfinance institutions (1995-2010). International Journal of Commerce and Management, 23(2), 148-174. https://doi.org/10.1108/10569211311324939

Ruch, W.A. (1982). The measurement of white-collar productivity. National Productivity Review, 1(4), 416-426. https://doi.org/10.1002/npr.4040010409

Sarkar, R. (2008). Public policy and corporate environmental behaviour: A broader view. Corporate Social Responsibility and Environmental Management, 15(5), 281-297. https://doi.org/ $10.1002 /$ csr.167

Saw, A.T.W., Kamarudin, F., \& Latiff, A.S.A. (2020). Price efficiency of Islamic and conventional banks: Evidence from Panel Data. International Journal of Economics and Management, 14(2), 301-310.

Schreiner, M. (2002). Aspects of outreach: A framework for discussion of the social benefits of microfinance aspects of outreach: A framework for discussion of social benefits of microfinance. Journal of International Development, 14(5), 591-603. https://doi.org/10.1002/jid.908

Steel, W.F., \& Andah, D.O. (2003). Rural and micro finance regulation in Ghana: Implications for development and performance of the industry (Africa Region Working Paper Series No. 49). Washington, DC: World Bank.

Sufian, F. (2009). Determinants of bank efficiency during unstable macroeconomic environment: Empirical evidence from Malaysia. Research in International Business and Finance, 23(1), 5477. https://doi.org/10.1016/j.ribaf.2008.07.002

Sufian, F., \& Kamarudin, F. (2014). The impact of ownership structure on bank productivity and efficiency: Evidence from Semi-Parametric Malmquist Productivity Index. Cogent Economics and Finance, 2(1), 1-27. https://doi.org/10.1080/23322039.2014.932700

Vanroose, A., \& D'Espallier, B. (2013). Do microfinance institutions accomplish their mission? Evidence from the relationship between traditional financial sector development and microfinance institutions' outreach and performance. Applied Economics, 45(15), 1965-1982. https://doi.org/10.1080/00036846.2011.641932

Wagner, C., \& Winkler, A. (2013). The vulnerability of microfinance to financial turmoil - evidence from the global financial crisis. World Development, 51(November), 71-90. https://doi.org/ 10.1016/j.worlddev.2013.05.008

Widiarto, I., \& Emrouznejad, A. (2015). The social and financial efficiency of Islamic microfinance institutions: A Data Envelopment Analysis application. Socio-economic Planning Sciences, 50(June), 1-17. https://doi.org/10.1016/j.seps.2014.12.001

Wijesiri, M., Yaron, J., \& Meoli, M. (2015). Performance of microfinance institutions in achieving poverty outreach and financial sustainability: When age and size matter? (MPRA Paper No. 69821). Munich, Germany: Munich University Library. Retrieved from https://mpra.ub.unimuenchen.de/69821/1/MPRA_paper_69821.pdf 
World Bank. (2018a). Bank Regulation and Supervision Survey Index. Retrieved from https://www. worldbank.org/en/research/brief/BRSS

World Bank. (2018b). World Development Indicators (WDI) Data Catalog 2018. Retrieved from https://datacatalog.worldbank.org/dataset/world-development-indicators

Zainal, N., Nassir, A.M., Kamarudin, F., Law, S.H., Sufian, F., \& Hussain, H.I. (2019). The social role of microfinance institutions in poverty eradication: Evidence from ASEAN-5 countries. International Journal of Innovation, Creativity and Change, 5(2), 1551-1576

Zainal, N., Law, S.H., Md Nassir, A., \& Bakri, M.H. (2020). Does the Malaysian Islamic money market efficiently predict inflation in the future? Evidence from the Fisher effect theory. International Journal of Innovation, Creativity and Change, 11(3), 665-682.

Zainal, N., Md Nassir, A., Kamarudin, F., \& Law, S.H. (2020). Does bank regulation and supervision impede the efficiency of microfinance institutions to eradicate poverty? Evidence from ASEAN-5 countries. Studies in Economics and Finance. Advance online publication. https:// doi.org/10.1108/SEF-10-2019-0414 
